\title{
Ruggiero and the Hippogriff: the Ambiguities of Vision
}

Characters of the Orlando Furioso soar above its vast epic universe on Ariosto's beast of fancy, the hippogriff. Offspring of a griffin and a mare, the winged steed combines the traits of its mythical sire with those of its equine maternal parent. By its very nature mediating between fantasy and reality, the hippogriff is the poet's symbol for the imagination. Ariosto assures us that "non è finto il destrier, ma naturale" (IV.18), ${ }^{1}$ despite its griffin-like plumage, head, and wings. With comically flawed logic, he demonstrates the reality of the hippogriff by explaining the nature of its origins. $\mathrm{He}$ repeats that "non finzion d'incanto .../ma vero e natural si vedea questo" (IV.19) and gently mocks the ungainly steed with multicolored wings. Ariosto thus insists on the reality of the hippogriff at the same time that he points to its partly mythical parentage, to its fanciful generation, and to its extraordinary appearance. Since this hybrid creature is so obviously imaginary, Ariosto's claim that it is true and real grants by implication ontological status to products of imagination.

The hippogriff offers those who mount it the possibility of flight, or airborne journeys unhampered by limitations of time or distance. Characters transported by the magical griffin-steed achieve a view of the entire universe: from their aerial vantage point, they perceive the world with a comprehensive and a simultaneous vision. Their perspective on the cosmos is thus analogous to the poet's conception of the universe he creates. Ariosto shares the capacity to envision with those characters who exercise even a modicum of control over the slightly absurd, often capricious, ippogrifo. Yet he consistently undermines the achievement of his fictive surrogates. Difficulties in managing the hippogriff are subject to comic scrutiny and, conversely, successful attempts to fly and to see are presented so ambiguously as to qualify their success. Through the ambiguities surrounding adventures on the winged steed - and particularly those of Ruggiero - Ariosto conveys his sense of his poetic enterprise. 
Ruggiero's initial flight on the hippogriff furnishes a magical means for transporting the cavalier from one imaginary location to another, from a fortress of illusion created for his benefit to an island paradise in which he nurtures his own illusions. When Ariosto picks up the thread of his story, Ruggiero is still astride the hippogriff, sailing his swift course beyond Europe, beyond the pillars of Hercules until, with large wheeling circles, his winged mount descends where he sees,

culte pianure e delicati colli,

chiare acque, ombrose ripe e prati molli. (VI.20)

Ruggiero lands in the deceptively beautiful garden of Alcina, a garden first associated with the imagination through the hippogriff's natural attraction to it. By endowing the island with the breezes, shade, and bird song of the conventional poetic pleasance, Ariosto confirms its relation to the creative imagination. Indeed, the attributes of the classical locus amoenus possess an exceptional appeal for the winged steed - "non vide né 'l più bel né '1 più giocondo/ da tutta l'aria ove le penne stese" (VI.20). But the limpid waters and lush foliage also resemble a place "pari a quella ove ... la vergine Aretusa passò invano/ di sotto il mar" (VI.19). The landscape, then, recalls the spot where a mythical virgin circumvented her own seduction. By alluding to the story of Arethusa, Ariosto creates a specifically literary context for the ensuing episode. He not only suggests the nature of Ruggiero's relation to Alcina, but he also evokes the fear, betrayal, and violence that form part of this myth. The allusion to Ovidian metamorphosis confers the legitimacy of his classical source on the connection between poetry and sinister reality. The reference to myth, the island's location beyond the limits of the known world, and the flight to this enchanting spot on the wings of fancy combine to suggest that Ariosto is leading the reader to an imaginary place in the regions of the mind.

The landscape of this earthly paradise quite literally embodies the products of the imagination, whether the transforming imagination of the magician or the similarly metamorphic power of the poet. The verdant hills and shaded banks that are its substance and its ornament are in fact the metamorphosed lovers of Alcina. The illusions of plants and animals that populate the island have a particularly literary status: the enchantress transforms men into beasts and strange hybrid creatures in the manner of her Homeric predecessor. But she also changes them into the lower form of vegetal existence, thereby debasing their human natures even 
further. The transformed courtiers provide the setting for the courtly love games in which they once participated: they comprise the leafy and fragrant enclosures in which others indulge a misguided sensuality. Degraded and misshapen, they are compelled into prurience and passive complicity in the degradation of their fellows. The palms and cedars concealing human forms and human personality thus recall the transformations of Circe. But the function of the metamorphosed lovers both in and as the landscape suggests Ariosto's attempt to modify, rather than merely assimilate, his classical source. Hence, the very flora and fauna of Alcina's island constitute a literary paragone and, typically, an assertion of poetic control. ${ }^{2}$

Alcina's minions also resemble Odysseus' men in some of their later literary and iconographic transformations. Those with human shapes and animal heads or hooves fall into this category, while those mounted on ox or eagle more closely resemble figures of medieval allegory. The captain of the grotesque crew, for example, drunkenly straddles a tortoise and makes his labored way along the road. The creatures who drink from cups recall the Homeric heroes, their readiness to down Circe's magic potion, and the enchanted cup as one of the chief iconographical details that identified the mage and her power. Others who bear ladders, hooks, and files suggest the devils of the fifth bolgia with their infernal hooks and grappling forks. ${ }^{3}$ The resemblance between the implements used by the creatures of Dante's Hell and the weapons of Alcina's band implies something about the nature of the fairy's paradise.

Ariosto's most extended treatment of a classical predecessor is, of course, his version of a man transformed into a speaking myrtle. Ruggiero encounters such a human plant when he lands on Alcina's island and ties the hippogriff to a tree. Like Vergil's Polydorus, the transformed Astolfo identifies himself, revealing the human nature confined within a vegetal exterior. Again, Ariosto does not merely assimilate his classical source but subjects it to the pressure of his comic imagination. He transforms the bleeding branches of Polydorus into fluttering foliage, loosened by the nervous response of an imaginary beast to some unknown sight or sound. The shying of the frightened hippogriff tied to its branches causes the plant to shake so violently that severed leaves clutter its base. The image of the hippogriff amongst the myrtle leaves suggests the distance between Ariosto's treatment of a metamorphosed human being and Vergil's.

Ariosto transforms Vergilian pathos with a deft comic stroke. Similarly, he alludes to Dante's version of the episode while 
largely divesting it of pathos. The struggles of the griffin-horse that cause the plant to suffer also motivate its speech. To describe the attempt by an imprisoned soul to create language, Ariosto employs a Dantean simile:

Come ceppo talor, che le medolle rare e vòte abbia, e posto al fuoco sia, poi che per gran calor quell'aria molle resta consunta ch'in mezzo l'empia dentro risuona, e con strepito bolle tanto che quel furor truovi la via; così murmura e stride e si coruccia quel mirto offeso, e al fine apre la buccia. (VI.27)

The simile which evokes Astolfo's attempt to speak recalls the manner in which the suicides are condemned to produce language in canto XIII of the Inferno. But here the offended myrtle frames sentences that are pronounced clearly and characterized by elegance of phrasing and courtly compliment. Ariosto creates a comic disjunction between the manner in which Astolfo in his plant form produces speech and the clear, intelligible quality of his words. Astolfo moans and shrieks, but when his plaintive voice issues finally from its constraining bark, it is "espedita e chiarissima" (VI.28). Furthermore, in his strident attempt to create language originates a compliment to Ruggiero's chivalry and an explicit appeal to his cortesia. There is a disjunction, then, between the articulate lament of the former paladin and the manner in which he is compelled to produce speech, and also between the courtesy of his address and its intent, which is to expedite his release from a nervous winged beast despoiling his foliage. The episode thus contains an element of comedy quite distinct from any parodic function it might have. While Ariosto's comic imagination transforms his Dantean source, his allusion to vernacular epic in part creates the brilliant surface of his poem.

The language used by the transformed peer itself constitutes part of Ariosto's literary allusion. The paladin/plant implores Ruggiero to free the restless hippogriff from his branches as befits a knight "cortese e pio" (VI.28). The appeal to Ruggiero's pietas explicitly connects the Italian cavalier with his Vergilian predecessor. But the comic nature of the situation suggests the difference between Ruggierc as "pio" and "pius Aeneas." Although, in his violation of the English peer, Ruggiero is the literary descendant of Aeneas, his purposes are not so noble nor his circumstances so compelling as those of the Vergilian hero. ${ }^{4}$ He discovers the transformed Astolfo 
quite by the way, and the episode has nothing of the grandeur associated with the epic theme of exile and return.

We have already remarked the courtesy that Astolfo even in his vegetal casing extends to the naively blushing knight. For his part, Ruggiero swears in the name of his lady to make amends for the damage done by the hippogriff. His language is courteous in the limited sense of being polite and chivalrous in the elegant form of his oath. But neither "courtesy" nor "chivalry" prevents his causing pain, nor does either help him determine the true nature of the speaking plant. Like Astolfo before him, Ruggiero assumes that things are what they seem, and so he accepts the appearance of the myrtle for its reality. He is unprepared to cope with the unexpected and unaware that the guidelines to his actions are fast becoming his limitations. Circumscribed by its own absolute prescriptions for behavior, the chivalric code itself, as A.B. Giamatti has pointed out, is inadequate for dealing with the unpredictable nature of reality. ${ }^{5}$ So, despite even the explicit warning of the transformed Astolfo, Ruggiero is deceived by the comeliness of Alcina and her island paradise.

Ruggiero's unreflective presuppositions about the world combine with a failure to interpret the projections of Alcina's more vivid imagination. That is, Ruggiero is not only subject to his own inadequate ideas about reality, such as the sufficiency of the chivalric code, but he is unable to recognize in his environment the manifestations of Alcina's magic. He does not understand, for example, the encounter with the giantess Erifilla or the island's very flora and fauna for the false illusions they are. Ruggiero's imaginative failure contrasts markedly with Ariosto's imaginative play in this episode: the increasingly serious consequences of his narrow perspective evolve with the unfolding of events. At the same time, Ariosto's engagement with his classical and vernacular predecessors becomes more prominent. With the rapid accretion of literary reference, he announces his epic pretensions, implies comparison with his predecessors, and asserts his original treatment of old stories. Ariosto's ability to create a narrative fabric of illusion by assimilating and transforming his sources appears at the same poetic moment as Ruggiero's failure to perceive even the presence of illusion. The poet clearly places himself in a position of artistic superiority to his fictive surrogate, Ruggiero, who belatedly learns that he must use the power of illusion to overcome his adversaries.

That illusion will provide him his release does not occur to the naive knight. But the reader can interpret the rapidly accreting references to magic transformation as the meaningful signs that 
they are. Ariosto insists on the necessary and beneficient power of illusion in effecting Ruggiero's rescue. The fay Melissa arrives miraculously transformed into the image of Atlante, mounted on a sprite "metamorphosed as a horse" (I.254), and armed with the magic ring "che val contra ogni magica fattura" (VII.47). She slips the ring on Ruggiero's finger and brings the knight back to his senses. Quite literally disillusioned, Ruggiero sees Alcina for the wizened, pale, and toothless hag she is. He recognizes, too, his false notions about the island paradise and the indulgence in sensuality that passes there for love.

Because Ruggiero now distinguishes appearance from reality, he can use the power of illusion for his own constructive ends. He leaves the false paradise "dissimulando" (VIII.3) ("by using guile," 1.263) and frees himself with Atlante's magic shield from the rabble who deter his escape. Although Ruggiero has learned to use both shield and ring, he has still to bring the steed of fancy under his control. Only then will he have mastered the ultimate symbol of the power of illusion, the creative imagination.

Until he is instructed in the ways of the hippogriff, Ruggiero takes flight only in a metaphorical sense. He purposefully refrains from riding the hippogriff out of Alcina's realm, since an airborne journey would create suspicion of his intended escape, and arrives at Logistilla's castle mounted on Rabicano, Astolfo's swift but ordinary steed. His earthbound and horizontal progress toward a goal appropriately images his limited capacity for vision and the circumscribed nature of his imagination. Ruggiero may have a limited imagination, but he nevertheless comprehends the conventional chivalric arts. He learns to apply the skills of horsemanship to his flying courser, instructed by Logistilla,

come egli abbia a far, se vuole

che poggi in alto, e come a far che cali;

e come, se vorrà che in giro vole,

o vada ratto, o che si stia su l'ali. (X.67)

That Ruggiero must be taught to manage the hippogriff by a beneficent lady magician suggests something about the knight, as well as about the nature of the beast. Without the superhuman intervention of Logistilla - her creation of bit and bridle, as well as her lessons in aerial horsemanship - Ruggiero could not venture skyward with any chance of achieving vision. He needs instruction in order to master the beast of fancy and become "d'ogni cosa in punto" (X.68). Without the action of a kindly mage, without the perspective that flight provides, the opportunity for interpreting the world would remain inaccessible to the knight. 
Illusion in its creative aspect - those appearances which reflect rather than distort the truth about reality - seems as dependent on magic power as release from false illusion. Although Ruggiero did not avail himself of his first opportunity for viewing the cosmos, Ariosto gives the knight another chance. It is to his subsequent adventures in flight that we now address ourselves.

Ruggiero's departure from Logistilla's realm differs from his hasty withdrawal from Alcina's. Securely mounted on the back of the hippogriff, he literally flies above the world of the poem. The metaphorical dimension of flight is that of achieving vision, not that of escape, the connection between sight and insight, seeing and imagining, signalled by the presence of the hippogriff. Ruggiero's newly acquired control over the winged steed provides the opportunity for vision that earlier remained inaccessible to him. This particular flight differs, then, not only from flight as escape, but also from flight as the failed attempt at vision. Now, when Ruggiero sets out, he,

...non rivenne

per quella via che fe' già suo mal grado,

allor che sempre l'ippogrifo il tenne

sopra il mare, e terren vide di rado.(X.69)

Ariosto is alluding, of course, to the cavalier's thorough inability to control the hippogriff on the first occasion on which he took to the air. Then he was swiftly transported out of Europe through the plotting of Atlante, "di cui non cessa la pietosa voglia/ di trar Ruggier del gran periglio instante" (IV.45). According to the enchanter's scheme, the ippogrifo had virtually presented itself to the unsuspecting knight. Ruggiero's apparent success in pursuing the elusive hippogriff merely conveys his susceptibility to powers outside himself. His rapid disappearance from regions perceived as dangerous by Atlante images his lack of control over the winged steed.

When, in canto X, Ariosto illustrates Ruggiero's ability to handle the hippogriff by negative comparisons with his previous difficulties, he creates a qualified image of his current success. The cavalier does not follow his previous course, one which, moreover, he had been compelled to pursue; he is not borne over the sea against his will; and he does not soar so high that he rarely has sight of land, let alone a better perspective of the world. By recalling Ruggiero's earlier subjugation to the whims of the 
hippogriff, Ariosto hardly conveys the knight's newly acquired competence. At the moment Ruggiero finally achieves a perspective over his world, Ariosto draws attention to the fiasco of his previous flight and implies all the subsequent failures of imagination to which that journey led him. Indeed, the narrative has just described precisely those events that followed Ruggiero's abduction on the hippogriff. By referring to the knight's former difficulties on the beast of fancy, Ariosto contributes to the ambiguity of Ruggiero's present achievement.

Although the description of Ruggiero's departure asserts his alleged control over the hippogriff, the image of his control is that of the random, often circular, motion of the quest: ${ }^{6}$

potendogli or far batter le penne

di qua di là, dove più gli era a grado,

vòlse al ritorno far nuovo sentiero.(X.69)

Ruggiero's ability to make a gentle ascent in a direction of his own choosing is imaged as the "di qua, di là" movement which signals the poem's quest motif. The pursuit of some elusive object of desire or value is itself ambiguous - indeed, such a pursuit explains the cause of Orlando's madness. That Ruggiero's control over the hippogriff bears an intrinsic relation to the ambiguities of questing thus qualifies the nature of his flight and the degree of control he exercises. The image of random and/or circular motion implies the limitations of this control insofar as he is attracted to the things of this world that are transient, mobile, and constantly in flux. But those are precisely the things of true value in their perpetual metamorphoses, their modifications to the exigencies of a changing reality. Ruggiero's arbitrary changes of direction imply, then, not only his newly acquired skill in manipulating the symbols, or manifestations, of illusion such as the ippogrifo; but the shifting, unpredictable movements of the knight entirely reflect the nature of the world above which he confidently soars. As Ruggiero decides,

finir tutto il cominciato tondo,

per aver, come il sol, girato il mondo,(X.70)

his journey images the futility of questing in its nature as unending pursuit, but it images its value as well.

Ariosto's narrator rehearses the places over which Ruggiero flies. He alludes to these various geographical locations as points in Ruggiero's continually changing path and refers to their being 
within the scope of his vision: he sees Cathay and Mangi pass beneath his gaze; he beholds Russia, Prussia, and Pomerania. His capacity for achieving vision seems to be the happy result of his new control over the griffin-steed. Yet Ariosto combines an implicit allusion to this control with a reference to Ruggiero's very ordinary needs. Because the cavalier has learned to alight as well as soar at will, his nightly descents imply the ability to guide his mount. With a fastidiousness perhaps a little surprising, given the exhilaration of speed, distance, and novelty, he tries "ogni sera ... schivando a suo poter d'alloggiar male"(X.73). Although his decision about where and when to land appears to suggest his newly achieved control, the mundane nature of the occasion and Ruggiero's excessive concern undermine the special quality of his expertise. Like the provision in the earthly paradise of "buona biada" for the hippogriff, lodging for an airborne knight is not neglected by the poet. Yet the very intrusion of such details suggests that Ariosto does not regard the visionary capacity of his fictive surrogate with complete seriousness.

Ariosto also levels criticism at Ruggiero for indulging his desire to see the world's variety and, therefore, of exercising his power to envision. The cavalier's appetite is whetted and,

gustato il piacer ch'avea di gire

cercando il mondo, non restò per questo(X.72)

until he had brought the whole universe within the compass of his sight. The narrator describes Ruggiero's pleasure in discovery as so great that it overcomes even his wish to see Bradamante, "ben che...fosse ogni desire/ di ritornare ...presto" (X.72). The implication is clearly that he is betraying his role as courtier and lover. According to the conventions of courtly behavior, his desire to see his lady ought to outweigh his curiosity. Hence, the imperatives of cortesia appear to conflict with his broadening perspective of the world. The nature of the verse itself contributes to the ambiguous impression of the knight. In the lines describing his wanderlust, Ariosto employs internal rhymes that succeed in trivializing the grandeur of Ruggiero's journey around the world. His taste ("gustato") for travel is such that he will not refrain ("non restò per questo") from indulging it until he has circled the world. Ruggiero's experience of vision is again imaged as specifically cyclic ("cercando il mondo"). The pattern of movement that describes the activity of achieving perspective over the universe thus resembles the movement of the quest. That is, the pursuit of vision is characterized by an ongoing circularity that reflects the 
characteristic pattern of chivalric action. If achieving an overview of the universe resembles the quest in direction, Ariosto implies an even more significant resemblance between the nature of the two activities: Ruggiero's achievement of perspective is, analogously, the pursuit of something apparently attainable, but which proves elusive, and is perhaps not attainable at all.

Thus, Ariosto points to the ambiguities in Ruggiero's pursuit of vision: the cyclic nature of his flight conveys the poet's reservations about his character. That Ruggiero interrupts his flight at regular intervals so that he might serve his human, earthbound needs contributes to the limited sense of his experience. And, finally, the implicit criticism of Ruggiero's priorities, the suggestion that he really ought to be pursuing Bradamante, completes this highly qualified picture. Given that this is also an image of the knight's success, of his ability to guide the winged steed of imagination, Ariosto's intent to undercut the achievement of his fictive surrogate and assert his own superiority seems quite clear.

Ariosto conveys his sense of his own poetic skill by the circumstances of Ruggiero's landing as well as by those of his flight. The cavalier directs the hippogriff to descend outside of London where he sees troops of soldiers display their colors as they march to the sound of trumpet and drum. When Ruggiero inquires about the occasion for the pageant, he learns that under the various banners are the hosts of Scotland, England, and Ireland. Following the parade, the troops will proceed to the shore where ships bound for France await their arrival. Not content with this general description of the men-at-arms and infantry, the knight whom Ruggiero addressed volunteers information about each troop. He explains that "quella bandiera grande,/ ch'insieme pon la fiordaligi e i pardi" (X.77) is Leonetto's; that the or and sable belongs to Worcester; and that Richard, Earl of Warwick, carries "nel campo verde tre bianche ale" (X.78). The detailed excursus on the various emblems does not further enlighten Ruggiero in any significant way. Rather, it serves to parody the Homeric catalogue. It is Ariosto's reminder to his audience that his tale of battle, and the battle itself, are of epic dimension. Ariosto toys with the presuppositions of epic - the magnitude and grandeur of the epic universe, its comprehensiveness, and its variety. By assimilating epic conventions into the fabric of his poem, he invokes the authority of his predecessors and asserts the nature of his own poetic enterprise. At the same time that he lays claim to generic significance, he demonstrates his own virtuosity: he subjects the Homeric catalogue to the demands of romance and absorbs it into the context of Charlemagne's holy war. As the anonymous knight describes the 
multi-colored banners, he confers the values of knightly achievement on the assembled host. The catalogue of ensigns thus appropriates epic grandeur for the world of the poem. Althought ostensibly for Ruggiero's information, it provides a pretext for Ariosto's indulgence in poetic display.

Since he has demonstrated his poetic skill and Ruggiero's limitations, Ariosto is now content to indulge the knight a little and allow him to dazzle an audience with a virtuoso performance of his own. While Ruggiero observes the armies who parade before him, a crowd forms to survey the hippogriff: "maraviglioso corre e stupefatto;/ e tosto il cerchio intorno gli fu fatto" (X.90). Just as Ruggiero directs his flying courser in a path that circles the whole world to bring all humanity and all its wonders within his view, the crowd forms a circle to view one man, and one of its novelties - "quella/ bestia... unica o rara" (X.90), the hippogriff. The pattern of their movement reflects, in little, the movement of Ruggiero: the circle from which they view the airborne cavalier resembles the grand circle of his journey. Indeed, the absorbed attention of the crowd implies their relation to Ruggiero's achievement of vision, and even their own inclination to pursue an elusive object of desire. Ruggiero avails himself of the captive audience and spurs his steed heavenward:

... per dare ancor più maraviglia,

e per pigliarne il buon Ruggier più gioco,

al volante corsier scuote la briglia,

e con gli sproni ai fianchi il tocca un poco:

quel verso il ciel per l'aria il camin piglia.(X.91)

If Ruggiero astonishes the multitude with his winged mount, he utterly amazes them when he soars aloft. He leaves each and every one "attonito" and shapes his course for Ireland. Just as Ariosto changes the subject of his narrative, just as he arbitrarily ends a canto or picks up the thread of an unfinished story, so Ruggiero leaves his audience gazing after him. Insofar as his flight on the hippogriff is a metaphor for the poet's imaginative activity, Ruggiero's change of location is analogous to Ariosto's narrative shifts. Thus, the cavalier now exhibits the control of the poet over his vision.

Our sense of Ruggiero's control derives only in part from the performance on his winged and multi-colored mount. It comes also from the difference between his perception of the regions over which he flies and our own. Whereas we, the readers of the poem, hear the same heraldic description and, to all intents and purposes, "di banda in banda/ [vedono] gl'Inglesi" (X.91) with Ruggiero, when the cavalier flies over Ireland, we do not share in his 
experience. While he sees "Ibernia fabulosa," we only hear of its presence by report. The narrator identifies Ireland for the reader by relating one of its myths: here St. Patrick dug the cave in which men are cleansed of their sins. The allusion to St. Patrick's legendary vision of Purgatory suggests a knowledge of Ireland distinct from Ruggiero's merely visual perception. The reader now understands a truth about Ireland that remains undisclosed to Ruggiero. Despite his aerial perspective, Ruggiero's capacity for sight does not imply a concomitant insight. The limitation of even a cosmic view of the world seems to imply the need for more than a single kind of vision. Even when an image of reality appears comprehensive, there are alternative images of the same reality and alternative ways of knowing those images. The story that identifies Ireland for the reader serves, then, to convey potential limitations in Ruggiero's notion of the world. And, of course, we are not disappointed in the expectation.

Ruggiero does not long enjoy the control that vision presupposes. As he pursues his course westward, he sees Angelica chained to the bare rock of the Isle of Tears. That very morning she had been bound there by the ruthless band who seize all comely women as food for a massive sea-monster, the orc. From the height of his aerial vantage point, Ruggiero initially perceives Angelica as a statue,

... finta

o d'alabastro o d'altri marmi illustri

. . su lo scoglio così avinta

per artificio di scultori industri.(X.96)

That the live damsel presents an image of a work of art to Ruggiero's imagination implies a creative response to his flight and its concomitant vision. Ruggiero's ability to interpret Angelica's immobile presence on the rock as the beautiful result of conscious artistic effort again suggests his control over the hippogriff and the metaphoric dimension of his flight. Unlike the readers of the poem, however, Ruggiero cannot know the even greater control exercised by Ariosto. He cannot know, for example, that his image of Angelica as a statue parallels the image of Olimpia that appeared earlier in the canto. Not only do the ladies each resemble a sculpted artifact, but they embody Ariostan metamorphoses of Ovidian myth. An abandoned Olimpia indulges her overwhelming despair in the words of Ovid's Ariadne of the tenth Heroides. Angelica, on the other hand, is bound to naked rock in the manner of her Ovidian predecessor. "Se non vedea la lacrima distinta .../ e l'aura sventolar l'aurate chiome" (X.96), Ruggiero would not 
have realized that this maiden lives and breathes. Ariosto here appropriates the details of his Ovidian source, as the stirring of Andromeda's hair and the tears that stain her cheeks reveal that she, too, is not marble, but a living woman. ${ }^{8}$ Just as Andromeda makes a futile gesture toward feminine propriety, so Angelica "coperto con man s'avrebbe il volto,/se non eran legate al duro sasso" (X.99). Ariosto here absorbs Ovid's comic image of maidenly pudor into his text. In addition, he develops the comic implications of his classical source by emphasizing the ridiculous or particularly human elements of his story. ' Whereas Ovid alludes to Perseus' winged feet grown heavy with the weight of ocean spray, Ariosto describes the thoroughly drenched wings of the hippogriff. While the classical hero merely avoids overburdening his soaked pinions, Ruggiero considers the feasibility of riding a sodden mount even as he struggles with the orc. Ruggiero's concern about the dampened state of the hippogriff hardly promotes a sense of his heroic stature. Similarly, his pursuit of the orc exhibits the vacillating movement of the quest with its ambiguous associations. The orc itself responds to the flitting image of the hippogriff's pinions in a motion that typifies the poem's central activity: ${ }^{10}$

L'orca, che vede sotto le grandi ale

l'ombra di qua e di là correr su l'onda,

lascia la preda certa litorale,

e quella vana segue furibonda:

dietro quella si volve e si raggira.(X.102)

So Ruggiero swoops and soars, striking where the monster might be fatally injured, but the beast eludes him - his pursuit is as vain as the orc's itself. Finally, he unveils Atlante's shield and the brilliant flash of light emanating from the enchanted weapon overthrows the orc. Although it floats upturned in the foaming sea, Ruggiero cannot wound it through its thick hide:

Di qua di là ... percuote assai,

ma di ferirlo via non truova mai.(X.110)

He has learned that the power of illusion is a viable and even necessary means for confronting hostile forces in the world. ${ }^{1}$ Although his use of "frodo" is appropriate, its efficacy is woefully limited. So the orc survives to threaten another naked lady.

Ruggiero's capacity to envision is modified and, finally, ambiguous; but his response to vision lacks even the saving grace of ambiguity. He rescues the lovely abbandonata from the predatory attentions of the sea-monster, only to subject her to his own. Even in mid-air, he reveals the appetitive side of his nature as he imagines "mille baci/... negli occhi vivaci" (X.112), and instead 
of circling the whole of Spain, narrows the circuit of his course to a convenient oakwood. Ruggiero finds a suitable spot to ravish Angelica in the shadowy clearing "dove ognor par che Filomena piagna" (X.113). The allusion to the young girl of Ovidian myth who was raped by her brother-in-law Tereus evokes a violent and exploitive sexuality. The poignant sadness of the story, like the violence it recalls, reflects on both the landscape and the ensuing action. It reflects, that is, on the comic image of Ruggiero frantically fumbling with his armor, the sole impedimerit to his desire, and interprets the quality of his response to Angelica. Although Ruggiero now controls the beast of the imagination, he has significant difficulty with the steed of his passions. ${ }^{12}$

Ruggiero's ability, then, to soar and to see is short-lived. His aid to Angelica originates in a chivalrous impulse, and his perception of her as a statue reveals an imaginative, even interpretive, response to her distress. Yet his capacity for sustaining a perspective on his world proves to be minimal. Indeed, the parallel between Ruggiero and the orc, the vain circularity of their movements and their misdirected appetites, conveys Ariosto's intent in portraying the limitations of this cavalier. Ruggiero's literal view of the poetic cosmos in no way approaches Ariosto's metaphoric vision in either clarity or comprehensiveness. $\mathrm{He}$ is unaware, for example, that Angelica's sculpted appearance balances the portrait of Olimpia immobilized with grief and literally statuesque. He imagines Angelica as an artifact, but the meaning of this idea of her remains undisclosed to him, whether as literary paragone or as part of the narrative pattern within the Furioso. In the first instance, the Ovidian nature of his situation - the parallel between his rescuing Angelica and Perseus' Andromeda - enriches Ariosto's poetic construct for readers of the Metamorphoses, Ruggiero not being among them. Then, as a participant in its fiction, Ruggiero cannot see his own function in the larger pattern of the poem; cannot, therefore, perceive his action as parallel to Orlando's in his rescue of Olimpia. While Ariosto creates a subtle and complex series of relationships both within the poem and between his poem and Ovid's, Ruggiero necessarily remains oblivious to this exercise of poetic control. The cavalier fittingly loses the hippogriff, who slips his bit "e [sale] in aria a più libero corso" (XI.13). 


\section{NOTES}

1 Ludovico Ariosto, Orlando Furioso, ed. Santorre Debenedetti and Cesare Segre (Bologna, 1960). References in parentheses are to canto and stanza. Translations are those of Barbara Reynolds, Orlando Furioso, 2 vols. (New York, 1975). References in parentheses are to volume and page number.

2 For a different, but not incompatible, interpretation of this episode, see William J. Kennedy,"Ariosto's Ironic Allegory," MLN, 88 (January 1973), 44-67.

3 See Dante Alighieri, La Divina Commedia, ed. C.H. Grandgent, rev. Charles S. Singleton, Inferno, canto XXI (Cambridge, Mass., 1972).

4 Aeneas tears branches from the myrtle bush/Polydorus as a cover for his altars: that the gods might protect him as he wanders in search of a new land, he offers sacrifices to their power.

5 See A. Bartlett Giamatti, The Earthly Paradise and the Renaissance Epic (Princeton, 1966), pp. 148-51.

6 D.S. Carne-Ross, "The One and the Many: A Reading of the Orlando Furioso," Arion, NS 3, No. 2(1976), 157-58.

7 See R.W. Hanning, "Ariosto, Ovid, and the Painters: Mythological Paragone in Orlando Furioso X and XI," Ariosto 1974 in America (Ravenna, 1976), p. 113.

$8 \mathrm{I}$ am indebted to Daniel Javitch's interpretation of this episode in his article, "Rescuing Ovid from the Allegorizers," Ariosto 1974 in America, pp. 85-98. See esp. pp. 94-97.

9 Cf. Javitch, p. 96.

10 Carne-Ross, p. 153n.

11 See A. Bartlett Giamatti, "Sfrenatura: Restraint and Release in the Orlando Furioso," Ariosto 1974 in America, p. 31. See also "The One and the Many," pp. 158 and 214-15n., and Edgar Wind, Pagan Mysteries in the Renaissance (New York, 1968), p. 154. 